\title{
Legislative production and public spending in France
}

\author{
François Facchini ${ }^{1} \cdot$ Elena Seghezza ${ }^{2}$ (D)
}

Received: 13 January 2020 / Accepted: 26 October 2020 / Published online: 8 December 2020

(c) The Author(s) 2020

\begin{abstract}
The aim of this article is to help explain the history of the public spending-to-GDP ratio in France by examining the production of laws and regulations. It empirically finds a positive and significant relationship between the number of pages in the Official Gazette of the French Republic and the development of the public expenditure-to-GDP ratio. We rely on the number of pages in the Official Gazette as a proxy for the cost of implementing laws and regulations. If unchecked, a proliferation of laws and regulations expands public spending. Over the period 1905-2015, a $10 \%$ increase in pages caused a $1.14 \%$ increase in the public expenditure-to-GDP ratio.
\end{abstract}

Keywords Public spending · Law · "Self-reinforcing" process

JEL Classification $\mathrm{H} 61 \cdot \mathrm{K} 20 \cdot \mathrm{N} 44$

\section{Introduction}

The aim of the present article is to help understand and explain the history of public spending in France. The history of gauging the size of the public sector by computing the public expenditure-to-GDP ratio is now well known. For many years, however, it was thought that one of the shortcomings of nineteenth- and twentieth-century French historiography related to the role of the state in economic development and, more generally, the very history of the state as a governing apparatus or machine (Bouvier 1978; Rosanvallon 1990). A proposed explanation for those shortcomings is the conscious or unconscious domination of the classical liberal approach to capitalism. Indeed, some scholars argue that liberal ideology is incapable of explaining the growth, in the long term, of state interventionism and its influence on economic development and, moreover, that it ignores the decisive role of the state in economic progress (Bouvier 1978). In 1983, Christine André and Robert

Elena Seghezza

seghezza@unige.it

François Facchini

francois.facchini@univ-paris1.fr

1 University of Paris 1 Panthéon-Sorbonne, Centre d'Economie de la Sorbonne, 106-112 Bd. de L'Hôpital, 75647 Paris, France

2 Department of Political Science, University of Genoa, Piazzale Brignole 3a, 16125 Genoa, Italy 
Delorme (1983) published a book that has become a standard reference. ${ }^{1}$ According to the authors, the increase in public spending and the role of the state in the economy more broadly was made necessary by market failures and the necessarily conflictual nature of social relations in a capitalist economy.

The explanation provided by the Ministry of Finance website for the growth in public spending is largely inspired by this work. It develops the idea that the growth of the public sector does not result from public decisions alone, but from the inability of markets to selfregulate. Endogenous growth theory holds that achieving high levels of economic growth requires ensuring that private enterprises have access to a well-educated and healthy workforce, roads, courthouses, researchers, and so on (Mills and Quinet 1992; Rajhi 1993; Artus and Kaabi 1993). The Marxist regulation school proposes a similar notion based on the class-struggle theory. Public spending is a means of producing social cohesion (Vianes 1980; Aglietta and Brender 1984). According to Aglietta (1997), state intervention is necessary to mitigate the lack of demand due to the impoverishment of shareholder employees caused by financial crises. In that context, the rise in public spending is not intended to undermine capitalism, but occurs because of it. Public spending mitigates market failures and serves to ameliorate social relations. It buys social peace. That conclusion is in keeping with Wagner's law. Capitalism promotes economic growth, and public spending rises as incomes expand.

The article at hand proposes and develops a very different position. Public spending is not a necessity, but rather the consequence of political choice. Government justifies the production of laws and regulations in order to protect citizens from all forms of insecurity. In that way, public spending expands inexorably.

As pointed out by Benjamin Constant, state intervention arises for two reasons: income redistribution and crises. ${ }^{2}$ Redistribution is a reason that is perfectly identified by the contemporary economic theory of public choice. The second source, crisis, is identified by the theme of security and protection. An explanation for governmental growth can be built on both notions. It is rooted in the fact that politicians act for themselves or on behalf of others to justify their existence. The consequence is that they must convince citizens of their usefulness. Politicians are useful if they enable citizens to externalize the costs of their choices to others (redistribution) or if they protect them from a source of danger. ${ }^{3}$ Threats, whether external or internal, exogenous or endogenous, necessarily generate a demand for protection. The existence of danger makes the politician's intervention useful. ${ }^{4}$

Danger produces fear, and fear justifies voting for laws that, once passed, must be enforced. Their implementation generates two types of costs: public, taxpayer-financed costs and private compliance costs. It is the latter that explains the expected close link between the production of laws and regulations and public spending; it gives rise to a selfreinforcing process of law and spending.

\footnotetext{
1 As Gilbert (1984) pointed out at the time, the idea was to contribute to knowledge about the economic role of the state in France by tracing the history of public spending.

2 See Higgs (1987).

3 The argument is put forward by Benjamin Constant (1822-1824) in his Commentary on Filangieri's Work.

${ }^{4}$ Historically, the main danger identified by politicians was the threat of invasion (Feldman 2008). Taxation was legitimated because war was imminent. Later on, many sources of danger, real and imagined, were put forward to justify state intervention: paternal tyranny, religious alienation, seigneurial exploitation, spoliation of workers by employers, merchants' dishonesty, the toxicity of certain goods, addiction (e.g., alcohol, sex, gambling, drugs), crime, pollution, poverty, and so on. Uncertainty and risk are related, but the former cannot be calculated probabilistically.
} 


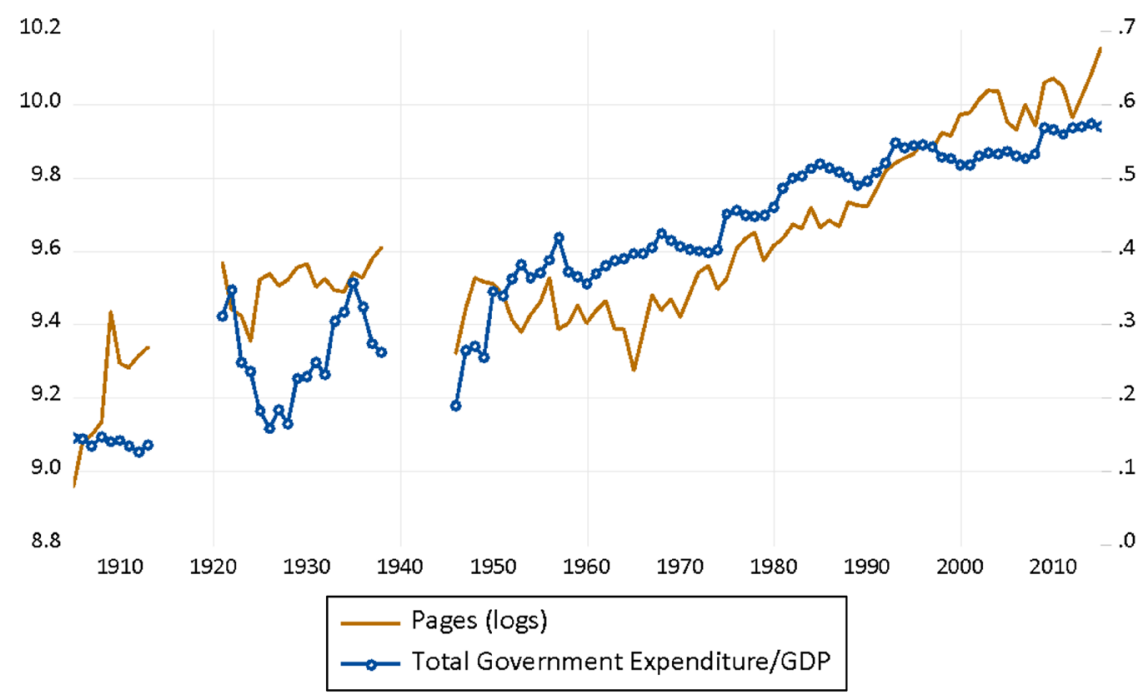

Legend: Legislative production is measured as the number of pages in the Official French Gazette (in logarithms). Total government expenditure is measured as a share of GDP.

Fig. 1 Legislative production and total government expenditure

A large body of literature has been dedicated to explaining public spending, ${ }^{5}$ but very few scholars have explored the link between public expenditure and legislation. ${ }^{6}$ This article proposes a theory of the dynamic interaction between law and public spending and tests the relationship with data on France spanning the period from the early 1900 s to 2015 .

\section{The effects of excessive laws and regulations on the public expenditure-to-GDP ratio}

The thesis proposed here is that one of the main reasons for the growth of public spending in a country like France is the production of laws and regulations. Figure 1 shows that legislative production was relatively modest before the First World War. It expanded significantly in the interwar period. It remained at comparatively low levels after the Second World War until the 1970s, after which it displayed a constant upward trend. The same figure also makes clear the close connection between the number of laws, expressed in logarithms, and the public expenditure-to-GDP ratio. ${ }^{7}$

The production of laws and regulations imposes direct and indirect costs that explain the increase in the public expenditure-to-GDP ratio.

\subsection{The direct effect of laws on public expenditure}

Laws influence the dynamics of government spending directly through their implementation costs. Such costs are administrative costs and compliance costs. Administration costs

\footnotetext{
5 See, among others, Facchini (2019).

6 See, among others, Shughart and Tollison (1986), Lagona and Padovano (2008) and Lagona et al. (2015).

7 The figure excludes the periods related to the twentieth century's two global wars.
} 
refer to all of the resources allocated by public and private administrations to implement laws and regulations. The costs of public administration correspond to the total number of working hours allocated by state employees to enforcing laws and promulgating regulations that give effect to enacted legislation. A traffic officer is paid to ensure that drivers fasten their seat belts, are not distracted by their mobile phones while driving, transport their children in suitable child seats, have certificates attesting that their vehicles have passed roadworthiness tests, and so on. The proliferation of laws and regulations justifies the hiring of new public servants, which increases public spending. A similar process occurs in the management of employment contracts. In 1892, for example, French politicians decided to ban the employment of children under the age of 8 . They then created a body of civil servants charged with implementing that law. In 1892, the number of labor law enforcers was set at 11 divisional inspectors and 92 département inspectors (Official Journal 1892). ${ }^{8}$ In 2015, the number of auditors and inspectors was 2188 (data from the Ministry of Labor). The comparison indicates a strong increase both in the number of rules governing employment contracts and in the costs of administering those laws. Concerning the United States, Dudley and Warren (2016) provide an estimate of the cost of enforcing regulatory protection measures. In 1960, the total spending of U.S. federal regulatory agencies was $\$ 3061$ million (in constant 2009 dollars). In 2016, it was \$60,666 million (Dudley and Warren 2016, Table 1.5 , p. 25). When the state extends its regulatory powers to every sector of the economy, it has to levy taxes to finance the salaries of the civil servants who ensure that regulations concerning competition, occupational health, the environment, gender parity, consumer safety, sustainability of production processes, and so on are enforced. The public costs of laws and regulations are a function of the salaries and numbers of civil servants who enforce them.

The costs of complying with regulations can also cause private businesses to adopt alternative production methods and the interest groups supporting them to adopt new political strategies. They may want to externalize the costs associated with complying with laws and regulations to society as a whole. Let us illustrate that scenario with an example, before discussing the rationales underlying the externalization of compliance costs. In 1999, the French government established a system of land-use contracts (Contrat Territorial d'Exploitation) and implemented a farming pollution management program (PMPOA). To prevent water pollution caused by the leaching of toxic substances contained in liquid swine manure, the government asked farmers to build concrete storage tanks. Generally speaking, farmers bear the costs of implementing sustainable agricultural practices (Facchini 2003). However, the costs associated with the PMPOA have not been borne by French farmers, but by the government, increasing, in such way, public expenditure. Thus, a chain of interventions was started that led to an increase in public spending.

\subsection{The indirect effect of the law on the public expenditure-to-GDP ratio}

Neither administrative expenses nor those associated with the externalization of compliance costs are productive expenses. The dynamic of state intervention is likely to have a negative effect on GDP growth through various channels: firstly, the production of laws, rules and their application; secondly, the fact that the law-expenditure dynamic is a

\footnotetext{
${ }^{8}$ Official Journal (Decree of December 13, 1892), http://solidarites-sante.gouv.fr/fichiers/numerisations3/ bull.insp.trav_1893.pdf.
} 
slippery slope, since law distorts relative prices and produces a chain of resource misallocations, creating the conditions for both new interventions and new expenditures (see Ikeda 1997). Lastly, other resources are wasted in rent seeking by interest groups to obtain measures favorable to them. Because rent seeking consumes scarce resources that could have been allocated to productive activities, excessive regulation is likely to hamper economic growth. Various scholars provide confirmation of such resource waste. Djankov et al. (2006, p. 1), for example, have observed that "using objective measures of business regulations in 135 countries, [we] establish that countries with better regulations grow faster. Improving from the worst quartile of business regulations to the best implies a 2.3 percentage point increase in annual growth". Based on a panel of 22 industries observed annually between 1977 and 2012, Cofrey et al. (2016) find that economic growth in the United States has slowed by $0.8 \%$ on average per year since 1980 owing to the cumulative effects of regulation. The production of excessive numbers of laws and regulations, therefore, slows GDP growth and contributes to increasing the public spending-to-GDP ratio.

\section{Data and model specification}

Our analysis seeks to determine whether and to what extent legislative production has influenced France's public expenditure. For that purpose, in addition to the number of pages in France's Official Gazette, expressed in logarithms, other variables that can affect total public expenditures have been entered as regressors in the empirical analysis. In particular, the following possible independent variables were considered.

\subsection{Political fragmentation}

As shown by Persson and Tabellini (1999), the more fragmented the makeup of government, the stronger is the pressure to expand public spending. Assuming that each ministry represents a type of organized interest (Volkerink and de Haan 2001), an index of political fragmentation - in the estimates FRAG-is given by the number of spendthrift ministers in the coalition government.

\subsection{Political ideology of government}

Political ideology is the traditional explanation for governmental growth provided by political science. Ideology captures the set of citizens' beliefs and values, in other words, their preferences. When voter political ideology shifts to the left, the socialization of risk is legitimated and public sector size increases (Pickering and Rockey 2011). Therefore, if the leftist composition of government rises and a leftist ideology is predominant in an electorate, we should observe more public spending.

To gauge the effect of political ideology on public spending dynamics, we rely on the percentage of seats held by right-wing deputies in the Lower Chamber of the French Parliament (Chamber of Deputies for the Third and Fourth Republic; National Assembly for the Fifth Republic), excluding French departments and overseas territories (1905-2012). On the basis of those data, it is thus possible to determine the parliamentary representation of the right (RIGHT) and of the left as a residual. 


\subsection{Fiscal federalism}

The level of governmental decentralization or centralization affects the dynamics of public spending. Fiscal decentralization refers to the degree of independent decision-making power at different levels of government in the provision of public goods and service (Oates 1972). A federal system generally is thought to be less favorable to public spending than a centralized system is, since it creates more intense political competition amongst political agents (Brennan and Buchanan 1980, p. 15), which limits fiscal illusion (Prohl and Schneider 2009) and the growth of total public spending. We enter the ratio of local tax revenues to total public revenues (FED) as a measure of the degree of fiscal decentralization.

\subsection{Unemployment}

The unemployment rate is intended to capture the importance over time of recourse to countercyclical fiscal policies, characterized by expansions in public spending and public budget deficits in the recessive phases of the business cycle. The expected sign on that variable-UNEMPL-is positive.

\subsection{Openness}

The extent of an economy's openness to international trade influences the volatility of its domestically produced output. Some studies find that openness increases that volatility (see Rodrik 1998; Easterly 2000; Kose et al. 2003) and therefore demands recourse to stabilization policies. In that case, one should expect a positive sign on that explanatory variable. Other studies, by contrast, find that trade, because of the diversification that it promotes in many cases, reduces the volatility of output (e.g., Cavallo et al. 2008; Burgess and Donaldson 2015; Haddad et al. 2013). If so, the sign of the variable—OPEN—should be negative.

\subsection{Financial repression}

The term financial repression indicates various policies that allow governments to underpay holders of publicly issued securities. Thus, high financial repression enables governments to reduce the cost of public debt (Reinhart et al. 2011; Reinhart and Sbrancia 2015). Financial repression derives from the inflation rate, which helps reduce the burden of the debt in real terms. Therefore, the variable REPR indicates the value of the debt/GDP ratio net of the inflationary erosion of the numerator. When inflation rises, the debt burden declines, i.e., REPR falls, which contributes to expansive debt-financed public spending. Hence, the expected sign of REPR is negative.

\subsection{Presidential form of government}

The establishment of a presidential form of government (PRES) in place of a parliamentary form is comparable to the establishment of a majoritarian regime. According to scholars 
like Persson and Tabellini (1999), such a form of government would then have a negative effect on public spending.

\subsection{The displacement effect}

The displacement effect (DISPL), pointed out for the first time by Peacock and Wiseman (1961), implies that if for some reason (wars, periods of social tension, austerity) ${ }^{9}$ or another citizens are required to pay more taxes, their level does not revert to the status quo ante once the extraordinary events have come to an end. ${ }^{10}$ The additional revenue obtained thanks to the restrictive fiscal measures adopted during crises offers policymakers resources to be used to grow public spending and gain electoral support. Therefore, the past ratio of taxation to GDP influences present government expenditure. Hence, the expected sign of DISPL is positive.

Bearing in mind the factors explained above, the empirical model takes as a point of reference an equation that is specified initially as follows:

$$
\begin{aligned}
\frac{G T O T}{G D P}= & a_{0}+a_{1} P A G E S+a_{2} F R A G+a_{3} R I G H T+a_{4} F E D+a_{5} U N E M P L \\
& +a_{6} \text { OPEN }+a_{7} R E P R++a_{8} P R E S+a_{9} D I S P L,
\end{aligned}
$$

where $\frac{G T O T}{G D P}=$ total government expenditures relative to GDP, and PAGES is the logarithm of the number of pages of the French Official Gazette. The main objective of the empirical model is to verify whether the number of pages of legislation, which can be considered as a proxy for the number of laws enacted and their complexity, has affected public expenditures of the French state.

\section{Estimates and results}

\subsection{Methodology}

The autoregressive distributed lag (ARDL) model put forward by Pesaran and Shin (1999) and later improved by Pesaran et al. (2001) is estimated herein. The model has various advantages when carrying out the test we wish to conduct.

Firstly, the ARDL model allows for an investigation of both short- and long-run relationships between variables at the same time. In addition, it makes possible the analysis of relationships between variables that do not have the same degree of integration. This methodology allows mixing as regressors variables that are $I(0)$ and $I(1)$. Care need only be taken to avoid I(2) variables in the estimates. Secondly, with ARDL, the problem of the endogeneity of the variables does not exist, since no residual correlation exists. ${ }^{11}$ Thirdly, compared to other methods, ARDL reduces the problems of sample size (see, among others, Nkoro and Uko (2016) and omitted variables.

\footnotetext{
9 Therefore, unlike Peacock and Wiseman (1961), who focus exclusively on military spending, we make reference to a more general form of this effect which, like the ratchet effect put forward by Higgs (1987), applies to a variety of crisis variables.

${ }^{10}$ Peacock and Wiseman (1961) provide historical evidence of this for England. Yelvington (1997) and Shughart (2018) give similar evidence for the United States.

11 The property is particularly relevant to the relation between DISPL and the dependent variable.
} 
The ARDL approach involves three steps. First, the order of integration of the variables must be checked. Even if ARDL allows the use of $I(0)$ and $I(1)$ variables, the method does not permit $I(2)$ variables. Secondly, the ARDL is estimated and the existence of any longterm relationships among the variables of interest is determined using the corresponding bounds test. That test is carried out by estimating an equation in which the first difference of the dependent variable is regressed on its own lags, on the first differences of the explanatory variables, both current and lagged, and on the one-period-lagged values of the dependent and explanatory variables. The optimal number of lags is chosen by the minimum Schwarz-Bayesian criterion (SBC). The test consists of an $F$-test on the joint significance of the level variables. The null hypothesis is that the variables are not cointegrated (all coefficients are jointly equal to zero), while the alternative is that the variables are cointegrated (the coefficients jointly are different from zero). The asymptotic distribution of the $F$-test is non-standard under the null hypothesis of no cointegration. The critical values were provided by Pesaran and Pesaran (1997) and by Pesaran et al. (2001). They consist of a lower and an upper bound. The lower bound's critical value assumes that the explanatory variables are stationary, while the upper bound's critical value assumes that they are integrated of order one. Therefore, if the $F$-statistic is less than the lower bound value, the null is not rejected, and we conclude that no long-run relationship exists between the variables. If the $F$-statistics exceeds the upper bound $F$-statistic, the variables are cointegrated. If the $F$-statistics fall between the two values, the result is inconclusive. Finally, the third step in the analysis estimates the coefficients of the long-run relationship and of the short-run elasticity of the variables with respect to the error correction representation of the ARDL model.

\subsection{Data}

As shown in the previous section, to investigate the nexus between total government expenditure to GDP and the number of pages in the French Official Gazette, we build a data set from several sources. The sources for the data are listed in the "Appendix". The main variable of interest, PAGES, is the (logged) number of pages of the French Official Journal. The number is determined by the last page of the December volume of the Journal Officiel de la République Francaise (JORF), whose editions are displayed in the "Appendix". ${ }^{12}$ Table 1 summarizes the descriptive statistics for the variables employed in our study.

\subsection{Unit root tests and multicollinearity test}

Based on the estimation procedure summarized above, the first step in the ARDL methodology is to check the order of integration of the variables. As is evident from the third column in Table 2, all the variables entered into the estimates satisfy the assumptions required; in other words, neither the dependent variable nor the regressors are $I(2)$.

\footnotetext{
12 The same indicator is adopted by the "Conseil d'Etat" to measure the volume of publications (Mesurer l'inflation législative, Annexe Indicateur de suivi de l'activité normative; see: https://www.conseil-etat.fr/ ressources/etudes-publications/rapports-etudes/etudes/mesurer-1-inflation-normative. On 1 January 2016, the JORF was completely dematerialized. As of that date, only an electronic version is available. For that reason, it no longer is possible to calculate the number of pages of the French Official Journal from the paper version, but only from the PDF version. The figures are very different, and therefore our estimates end in 2015.
} 
Table 1 Descriptive statistics

\begin{tabular}{lrcccl}
\hline & Mean & Maximum & Minimum & SD & Obs. \\
\hline GTOT/GDP & 0.39 & 0.57 & 0.13 & 0.14 & 98 \\
PAGES & 9.61 & 10.15 & 8.96 & 0.25 & 98 \\
REPR & 0.03 & 0.43 & -0.16 & 0.07 & 98 \\
DISPL & 31.47 & 45.61 & 11.42 & 11.10 & 98 \\
OPEN & 35.82 & 61.75 & 15.53 & 12.72 & 98 \\
FRAG & 31.85 & 59.00 & 14.00 & 10.39 & 98 \\
UNEMPL & 4.94 & 12.10 & 0.90 & 3.74 & 98 \\
FED & 12.04 & 21.10 & 4.60 & 3.60 & 98 \\
RIGHT & 0.53 & 0.86 & 0.20 & 0.18 & 98 \\
PRES & 0.58 & 1.00 & 0.00 & 0.50 & 98 \\
INTENSITY & 3.09 & 4.05 & 1.35 & 0.90 & 98 \\
\hline
\end{tabular}

Pages are expressed in logarithms

Table 2 Unit root tests

\begin{tabular}{|c|c|c|c|c|c|}
\hline & \multirow{2}{*}{$\begin{array}{l}\text { ADF test } \\
t \text {-statistic }\end{array}$} & \multirow{2}{*}{$\begin{array}{l}\text { Phillips-Perron test } \\
t \text {-statistic }\end{array}$} & \multirow{2}{*}{$\begin{array}{l}\text { Test for } I(2) \\
\text { ADF test }\end{array}$} & \multicolumn{2}{|c|}{$\begin{array}{l}\text { Unit root test with a struc- } \\
\text { tural break }\end{array}$} \\
\hline & & & & $t$-statistic & $\begin{array}{l}\text { Unknown } \\
\text { date of break }\end{array}$ \\
\hline GTOT/GDP & -1.78 & -0.18 & $-7.29 * * *$ & -3.80 & 1928 \\
\hline PAGES & -0.28 & -1.36 & $-10.01 * * *$ & -3.60 & 1924 \\
\hline FED & -2.86 & -2.85 & $-4.03 * * *$ & -3.91 & 1932 \\
\hline FRAG & -1.60 & -2.22 & $-20.63 * * *$ & $-5.29 * * *$ & 1943 \\
\hline REPR & $-3.63 * * *$ & $-3.73 * * *$ & $-13.17 * * *$ & $-5.70 * * *$ & 1945 \\
\hline UNEMPL & -2.03 & -1.96 & $-11.65^{* * *}$ & $-5.18^{* * *}$ & 1938 \\
\hline RIGHT & -2.22 & $-3.34 * * *$ & $-8.28 * * *$ & $-4.78 * * *$ & 1919 \\
\hline OPEN & -0.55 & -1.15 & $-11.43^{* * *}$ & -2.25 & 1968 \\
\hline PRES & -2.15 & -2.20 & $-10.14 * * *$ & $-9.86 * * *$ & 1957 \\
\hline DISPL & 2.59 & 1.57 & $-16.43^{* * *}$ & -2.64 & 1949 \\
\hline INTENSITY & -1.40 & -1.40 & $-11.86 * * *$ & -3.69 & 1938 \\
\hline
\end{tabular}

Legend: The null hypothesis is that the variable has a unit root. The ADF test equation includes an intercept and, where significant, a trend. The number of lags included was chosen with the Schwarz information criterion starting from a maximum of 6 lags. $* * *$ means rejection at $99 \%$, so variables with stars are stationary while variables with no stars are integrated of order one

In particular, according to the ADF and Phillips-Perron tests, all of the variables are I(1) except REPR, which is stationary. However, the findings are mixed for RIGHT, which is $I(0)$ on the Phillips-Perron test and $I(1)$ on the ADF test.

As is well known, unit root tests fail to reject the unit root hypothesis if the series contain a structural break. In the last column of Table 2 we run a unit root test with a structural break at an unknown date. Some variables do not change their statistical characteristics even when structural breaks are taken into account. Other variables, on the other hand, in particular FRAG, UNEMPL, RIGHT and PRES, become stationary. 
Table 3 VIF multicollinearity test

\begin{tabular}{lll}
\hline & VIF & $\begin{array}{l}\text { Tolerance } \\
(1 / \text { VIF })\end{array}$ \\
\hline PAGES & 6.33 & 0.16 \\
FED & 3.80 & 0.26 \\
FRAG & 3.35 & 0.30 \\
REPR & 1.29 & 0.78 \\
UNEMPL & 8.77 & 0.11 \\
RIGHT & 2.58 & 0.39 \\
OPEN & 5.28 & 0.19 \\
PRES & 6.16 & 0.16 \\
DISPL & 9.74 & 0.10 \\
\hline
\end{tabular}

Because the data set mixes $I(0)$ and $I(1)$ variables, the ARDL methodology appears to be the most suitable one available for estimating the determinants of public spending in France.

The regression analysis can efficiently estimate the relationship between the independent variables and the dependent variable if a non-perfect linear relationship exists between the independent variables - in other words, if multicollinearity is not evident. To establish multicollinearity's presence or absence, we apply the variance inflation factor (VIF) test (see Myers 1990).

If the VIF value exceeds 10, a strong linear relationship exists. The values given in Table 3 show that no independent variable has a VIF above 10. We can therefore exclude multicollinearity issues among the independent variables.

\subsection{Cointegration test}

The second step in the ARDL methodology consists in testing whether the variables entered into the empirical model are cointegrated. Prior to that test, we first needed to choose the number of lags to introduce into the ARDL estimates. To do so, we chose a maximum of four lags. Starting from that number, the Schwartz criteria select the optimum number of lags for each variable.

From the results of the estimates (Table 4) carried out using the optimal lag lengths thus obtained, it is evident that the $F$-value always exceeds the upper bound. That result allows us to conclude that the variables entered are indeed cointegrated.

\subsection{Results}

Lastly, we consider the long-run coefficients from the ARDL reported in Table 4, column (1), which shows that, as expected, PAGES is significant and bears the expected sign. Various other variables, on the other hand, are largely insignificant. Column (2) therefore does not include RIGHT, FED or PRES. Column (2) implies that FRAG remains insignificant.

The final equation, then, is the one reported in column (3). Based on the Cusum and Cusum square tests it is stable.

This estimate indicates that the level of French public spending in relation to GDP is influenced not only by the number of pages of laws passed, but also by the displacement effect, the degree of the country's openness, its level of financial repression and its 
Table 4 Long-run coefficients (dependent variable: total government spending to GDP)

\begin{tabular}{|c|c|c|c|}
\hline Variables & (1) & (2) & (3) \\
\hline PAGES & $\begin{array}{l}0.086 * * \\
(0.043)\end{array}$ & $\begin{array}{l}0.118^{* * * *} \\
(0.024)\end{array}$ & $\begin{array}{l}0.114 * * * \\
(0.023)\end{array}$ \\
\hline FRAG & $\begin{array}{l}-6.98 E-05 \\
(0.001)\end{array}$ & $\begin{array}{l}0.0003 \\
(0.0004)\end{array}$ & \\
\hline RIGHT & $\begin{array}{l}0.024 \\
(0.033)\end{array}$ & & \\
\hline FED & $\begin{array}{l}0.002 \\
(0.002)\end{array}$ & & \\
\hline UNEMPL & $\begin{array}{l}0.004 \\
(0.003)\end{array}$ & $\begin{array}{l}0.003 * * \\
(0.002)\end{array}$ & $\begin{array}{l}0.004 * * \\
(0.002)\end{array}$ \\
\hline OPEN & $\begin{array}{l}-0.0015^{*} \\
(0.001)\end{array}$ & $\begin{array}{l}-0.002^{* * * *} \\
(0.000)\end{array}$ & $\begin{array}{l}-0.0017 * * \\
(0.000)\end{array}$ \\
\hline REPR & $\begin{array}{l}-0.22 * * \\
(0.09)\end{array}$ & $\begin{array}{l}-0.478 * * * \\
(0.126)\end{array}$ & $\begin{array}{l}-0.463 * * * \\
(0.122)\end{array}$ \\
\hline PRES & $\begin{array}{l}-0.008 \\
(0.019)\end{array}$ & & \\
\hline DISPL & $\begin{array}{l}0.011 * * * \\
(0.001)\end{array}$ & $\begin{array}{l}0.010 * * * \\
(0.000)\end{array}$ & $\begin{array}{l}0.010 * * * \\
(0.000)\end{array}$ \\
\hline $\mathrm{C}$ & $\begin{array}{l}-0.765^{* * *} \\
(0.359)\end{array}$ & $\begin{array}{l}-1.018 * * * \\
(0.216)\end{array}$ & $\begin{array}{l}-0.976^{* * * *} \\
(0.205)\end{array}$ \\
\hline \multicolumn{4}{|c|}{ Sample period: 1905-2015 } \\
\hline No. obs. & 96 & 90 & 90 \\
\hline Bound test & $3.6^{* *}$ & $6.89 * * *$ & $7.84 * * *$ \\
\hline ARDL order & $(1,1,2,1,3,0,1,0,0,0)$ & $(4,0,2,1,3,0,1)$ & $(4,0,2,1,3,1)$ \\
\hline
\end{tabular}

Legend: ***rejection at $99 \%$, **rejection at $95 \%$, *rejection at $10 \%$. Stars in the bound test mean that the variables are cointegrated

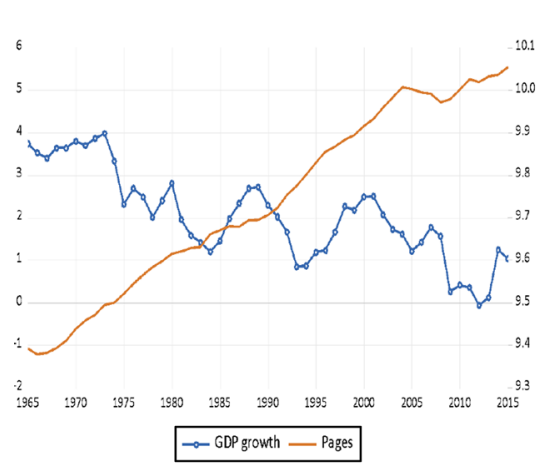

(a)

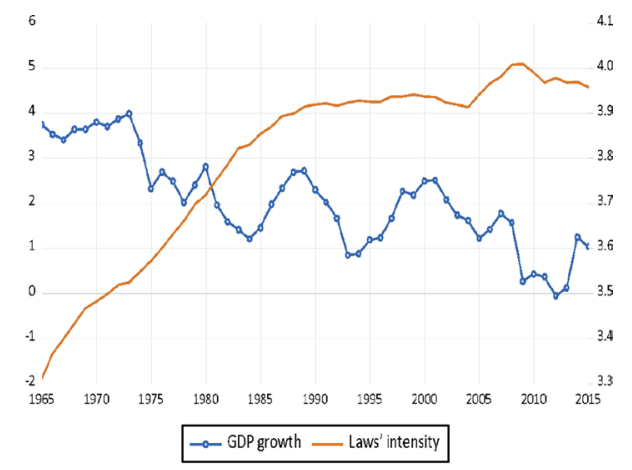

(b)

Legend: Both variables are 5 -year averages.

Fig. 2 Legislative production and economic growth

unemployment rate. In particular, as is to be expected, when financial repression is heavy, and therefore the public debt-to-GDP ratio corrected for that effect (REPR) weakens, the public expenditure-to-GDP ratio rises, while increases in displacement and unemployment have positive effects on the ratio. The results suggest that more openness of the French 


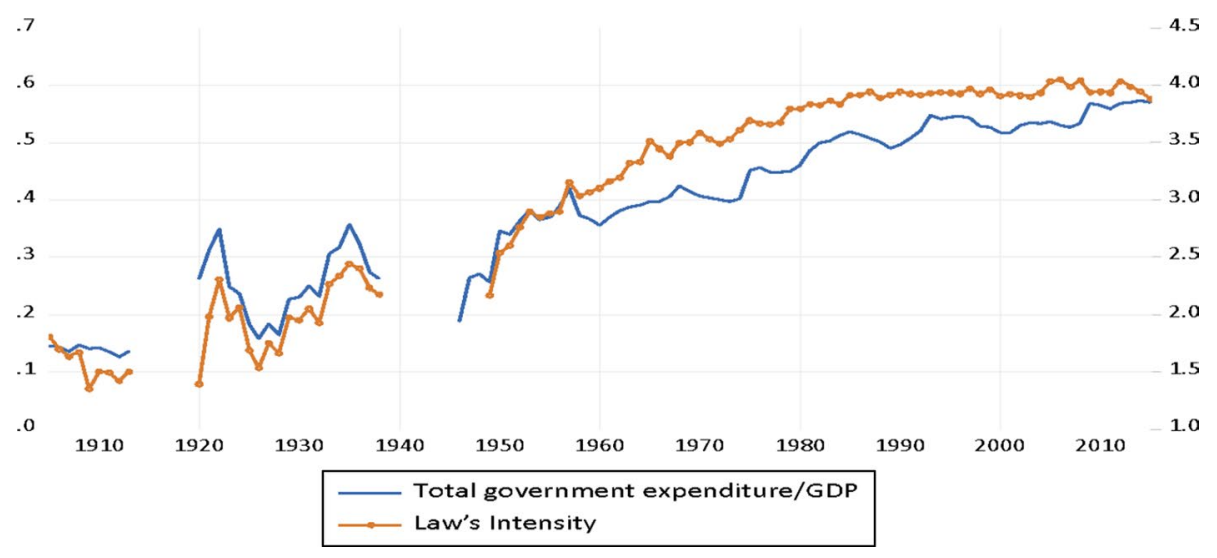

Fig. 3 Intensity of spending and public spending/GDP

economy to international trade negatively affects the public expenditure-to-GDP ratio. It would appear, therefore, that in the case of France, the effects of the diversification of exports offset the output repercussions of any possible foreign trade shocks.

\subsection{The robustness test}

The estimates reported in Table 4 show that the number of pages of laws enacted affect the public expenditure-to-GDP ratio. It is important, however, to establish whether that influence has become stronger with time, that is to say, whether the extent of French government intervention in the economy has increased over time and, if so, the ways in which it has happened.

Part (a) of Fig. 2 shows that the French government's production of legislation intensified significantly after the Second World War. ${ }^{13}$ Considering a 5-year moving average, as a way of smoothing economic cycles, the figure shows a strong inverse correlation between the numbers of laws produced and the economy's rate of growth since $1965 .^{14}$

It can therefore be said that growth in legislation led to growth in the public expenditure-to-GDP ratio by slowing the growth of the denominator. However, legislation has also influenced the numerator's time trend. Figure 3 demonstrates that French government spending per page of legislation (which can be taken as a measure of the public spending associated with each law) shows a close correlation with the trend in the public-spending-to-GDP ratio. The correlation is very close after the Second World War, during which period both government spending per page-henceforth, the intensity of spending - and the public spending-to-GDP ratio rose sharply until the 1980s. Their values later stabilized.

\footnotetext{
13 The finding confirms the argument put forward by Facchini and Melki (2013), according to which a negative link between public expenditure and growth has become particularly relevant since the 1960s.

14 An ordinary least squares (OLS) regression estimated over the period 1910-2011 shows that a $1 \%$ increase in the 5-year average of laws produced is associated with a drop in the 5-year average growth rate of 0.1 percentage points per year.
} 


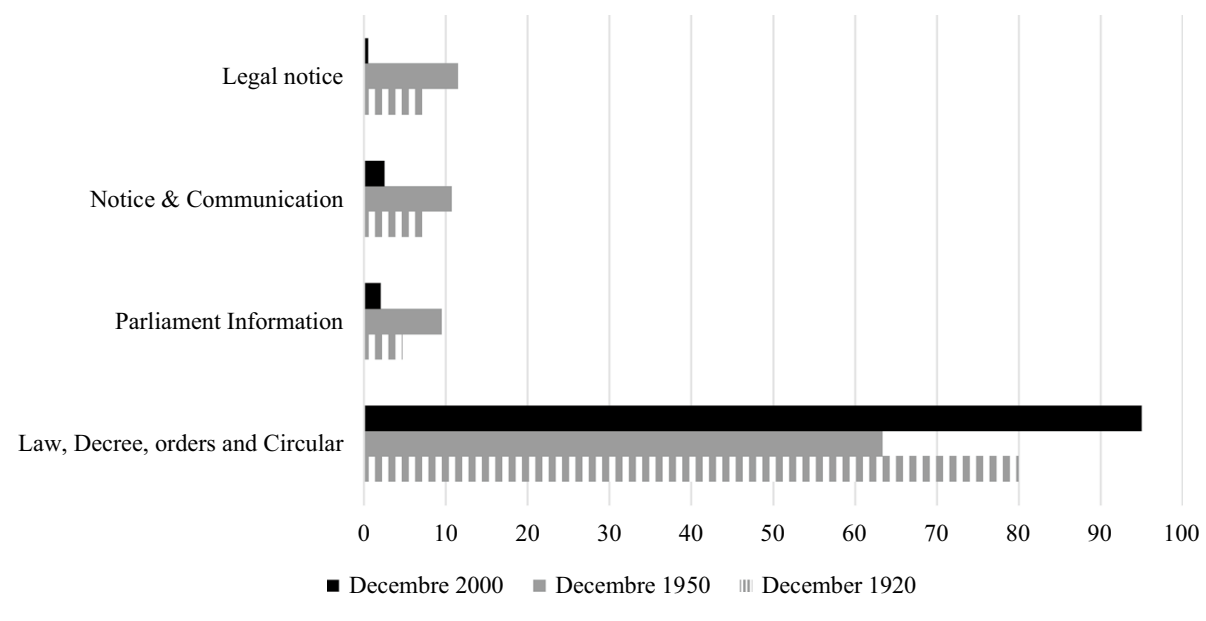

Source: Indicateurs de suivi de l'activité normative, Premier Ministre, Service général du gouvernement, 2018.

Fig. 4 The structure of Official Journal

The increase in the intensity of spending indicates growing levels of state intervention in the economy. While during the period before the First World War such intervention was often in the form of regulatory measures and rules, in the post-war period it primarily took the form of spending laws, most of which had the purpose of expanding the welfare state. That shift occurred already in the period immediately following the Second World War. In subsequent decades, the tendency to adopt measures of social protection became consolidated with governments of different political hues as well. As Fig. 2b shows, public spending per law passed is associated with a decline in the economy's growth rate.

In order to clarify the factors that contributed over time to raising spending intensity, we carried out a robustness test, entering real public expenditure per law, i.e., INTENSITY, as a dependent variable, and the same control variables entered into the estimates reported in Table 4 as regressors. As before, we applied the ARDL methodology; the reference sample remains the same.

We first tested for multicollinearity. As shown by the VIF test in Table 5, no independent variable has a VIF above 10. Thus, we again can exclude problems of multicollinearity among the independent variables.

Table 6 shows the long-run coefficients from the ARDL for the spending intensity associated with laws enacted. As is clear from column (1), FED and UNEMPL appear to have no influence on the intensity of spending. Those variables drop from the model in column (2), which also shows that RIGHT becomes insignificant.

In the estimates of column (3), all variables are significant. The Cusum and Cusum square tests shows they are stable.

The signs of the variables are as expected, apart from PRES, which carries a positive as opposed to a negative sign, indicating that a presidential form of government brings with it an increase in spending intensity on a par with the fragmentation index (FRAG) and the displacement effect (DISPL). Conversely, increases in REPR and OPEN contribute to reducing public spending per page of laws passed. 
Table 5 VIF multicollinearity test (dependent variable: spending intensity)

\begin{tabular}{lll}
\hline & VIF & $\begin{array}{l}\text { Tolerance } \\
(1 / \text { VIF })\end{array}$ \\
\hline FED & 3.48 & 0.29 \\
FRAG & 3.53 & 0.28 \\
REPR & 1.13 & 0.88 \\
UNEMPL & 8.16 & 0.12 \\
RIGHT & 1.91 & 0.52 \\
OPEN & 3.64 & 0.27 \\
PRES & 4.85 & 0.21 \\
DISPL & 9.12 & 0.11 \\
\hline
\end{tabular}

Table 6 Robustness test (dependent variable: spending intensity)

\begin{tabular}{|c|c|c|c|}
\hline Variables & (1) & (2) & (3) \\
\hline FRAG & $\begin{array}{l}0.007 * \\
(0.004)\end{array}$ & $\begin{array}{l}0.008 * * \\
(0.003)\end{array}$ & $\begin{array}{l}0.006 * * \\
(0.003)\end{array}$ \\
\hline RIGHT & $\begin{array}{l}0.333 * \\
(0.183)\end{array}$ & $\begin{array}{l}0.271 \\
(0.167)\end{array}$ & \\
\hline FED & $\begin{array}{l}-0.011 \\
(0.0125)\end{array}$ & & \\
\hline UNEMPL & $\begin{array}{l}0.017 \\
(0.017)\end{array}$ & & \\
\hline OPEN & $\begin{array}{l}-0.006 * \\
(0.004)\end{array}$ & $\begin{array}{l}-0.006 * * \\
(0.003)\end{array}$ & $\begin{array}{l}-0.007 * * * \\
(0.003)\end{array}$ \\
\hline REPR & $\begin{array}{l}-3.238 * * * \\
(1.215)\end{array}$ & $\begin{array}{l}-3.937 * * * \\
(1.154)\end{array}$ & $\begin{array}{l}-3.851 * * * \\
(1.088)\end{array}$ \\
\hline PRES & $\begin{array}{l}0.284 * * \\
(0.121)\end{array}$ & $\begin{array}{l}0.292 * * * \\
(0.106)\end{array}$ & $\begin{array}{l}0.379 * * * \\
(0.082)\end{array}$ \\
\hline DISPL & $\begin{array}{l}0.055 * * * \\
(0.007)\end{array}$ & $\begin{array}{l}0.062 * * * \\
(0.005)\end{array}$ & $\begin{array}{l}0.064 * * * \\
(0.004)\end{array}$ \\
\hline $\mathrm{C}$ & $\begin{array}{l}1.128 * * * \\
(0.322)\end{array}$ & $\begin{array}{l}0.874 * * * \\
(0.131)\end{array}$ & $\begin{array}{l}0.994 * * * \\
(0.088)\end{array}$ \\
\hline \multicolumn{4}{|c|}{ Sample period: $1905-2015$} \\
\hline No. obs. & 91 & 89 & 89 \\
\hline Bound test & $3.82 * * *$ & $5.59 * * *$ & $7.72 * * *$ \\
\hline ARDL order & $(2,2,3,0,1,0,0,0,0)$ & $(2,2,5,0,1,0,0)$ & $(3,2,1,0,1,0)$ \\
\hline
\end{tabular}

Figure 2a, b show that in post-war France, interference by the state in the economy increased in terms of both more active market regulation and total public spending. It was during the post-war period that the idea of more state intervention in the economy took the upper hand amongst France's political class. ${ }^{15}$ The dominance of that ideological orientation

\footnotetext{
15 The differing extents of interference by the state in the French economy in the preceding period and in the period immediately following the Second World War shows that, as pointed out by Lamoreaux and Rosenthal (2005), intervention did not depend on the presence of civil law or common law institutions, as maintained by the Law and Finance hypothesis, but rather on the ideological orientations of the respective governments. On the importance of ideological orientation in the passing of laws by elected bodies, see, in particular, Roe (1994, 2003).
} 
70 30000

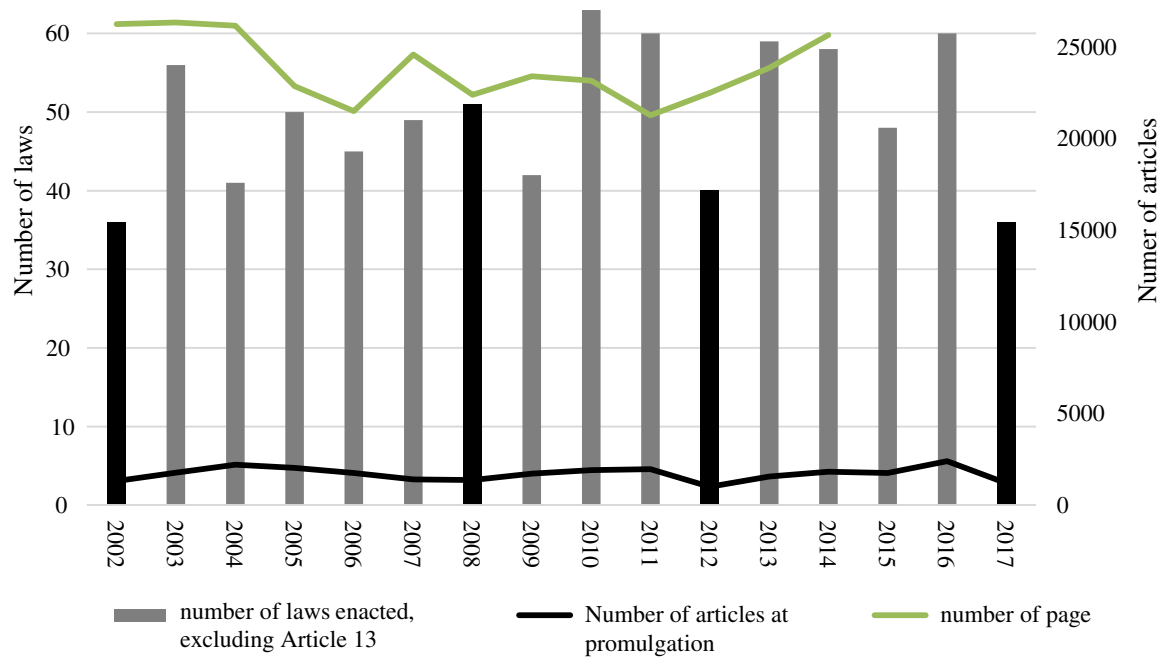

Source: Indicateurs de suivi de l'activité normative, Premier Ministre, Service général du gouvernement, 2018.

Fig. 5 Comparison of the number of laws and the number of articles at the promulgation (2000-2017)

translated above all into regulatory interventions that changed relative prices and the costs of producing goods. ${ }^{16}$ Indeed, between 1944 and 1946 the French government under Charles De Gaulle, invoking the need to promote the reconstruction of the country, undertook the nationalization of various companies in the energy, transportation and finance sectors.

The second type of state intervention, namely the rise in public spending associated with the passing of legislation, began to be adopted on a massive scale, especially from the latter half of the 1960s onwards, when Keynesian ideology came to prevail in the government's approach to economic policy.

However, the nexus between the total number of laws and the spending associated with each law is also endogenous: legislative intervention by the state leads to additional spending on the implementation of the laws in question. It is no accident, therefore, that, as Fig. 3a, b show, a rise in spending intensity corresponds to an increase in legislative production.

As we said in the introduction, rulers regulate the economic and social lives of citizens in response to real or presumed sources of danger. Such regulation brings with it more public spending. The self-reinforcing association between laws and public spending can be explained by paternalistic attitudes or by the vote motives animating popularly elected politicians. The multiplicity of dangers and their constant renewal bring extensions of the state into all areas of life. Perception of mounting risks and sense of urgency become the driving force behind public intervention and ultimately increases in public spending. Paternalism justifies the production of laws and regulation under the guise of protecting citizens from themselves. That governmental attitude applies especially to France. Charles de Gaulle once wrote that "France can only maintain itself through the state. Nothing is more important than the legitimacy, the institutions and the functioning of the state... I am sure

16 The measures were typical of regulatory-state capitalism (see Mises 1929 and Ikeda 1997). 
that I will find in the Conseil d'Etat the support that it has always provided to the Republic and to France". ${ }^{17}$ In that perspective, public service is "an activity of general interest managed under the control of a public person".

\section{Conclusions}

This paper has shown empirically that in France, over the period 1905-2015, the production of legislation led to increases in the ratio of public spending to GDP. Fundamentally, one can advance three reasons for that finding. On the one hand, the passing of laws inevitably leads to an expansion of the administrative apparatus needed to implement and enforce compliance with laws passed. Secondly, a plethora of laws and regulations has a negative effect on the efficiency with which resources are allocated by the private sector, leading to a slowing of economic growth and, thus, of GDP. Thirdly, starting from the period immediately following the Second World War, the intensity of spending associated with laws increased progressively, especially so in support of an expanded welfare state, and this also led to an increase in the public expenditure-to-GDP ratio.

The considerable contribution of laws to increases in the spending-to-GDP ratio, as reported herein, is consistent with the increasingly paternalistic attitude of policymakers. When individuals give in to this attitude, the role of the state in the economy expands, as does public spending. These results could provide motivation for a study on the effects of laws' production on the single components of public expenditure.

Funding Open access funding provided by Università degli Studi di Genova within the CRUI-CARE Agreement.

Open Access This article is licensed under a Creative Commons Attribution 4.0 International License, which permits use, sharing, adaptation, distribution and reproduction in any medium or format, as long as you give appropriate credit to the original author(s) and the source, provide a link to the Creative Commons licence, and indicate if changes were made. The images or other third party material in this article are included in the article's Creative Commons licence, unless indicated otherwise in a credit line to the material. If material is not included in the article's Creative Commons licence and your intended use is not permitted by statutory regulation or exceeds the permitted use, you will need to obtain permission directly from the copyright holder. To view a copy of this licence, visit http://creativecommons.org/licenses/by/4.0/.

$\overline{17}$ Quoted in Rangeon (1986, p. 14). 


\section{Appendix}

\section{A.1. Description and sources of variables}

\begin{tabular}{lll}
\hline Name & Description & Source \\
\hline GTOT/GDP & Total government expenditure net of public & 1905-1938 and 1947-1958. Flora (1983) \\
& investment/GDP & 1959-2015. INSEE: \\
& Expenditures and receipts of general govern- & ment https://www.insee.fr/en/statistiqu \\
& es/2387925?sommaire=2387999 \\
& Gross domestic product and its components at \\
& current prices (billions of euros) \\
https://www.insee.fr/en/statistiques/23878 & 82 sommaire=2387999
\end{tabular}

PAGES Number of pages (in logs) of the French Official Journal

Share of local source tax revenue in total revenue $(\%)$

FRAG Number of spendthrift ministers in the coalition government
The number is the last page of the December volume of the French Official Journal (JORF). The same indicator is used by the "Conseil d'Etat" to measure the volume of publication (Mesurer l'inflation législative, Annexe Indicateur de suivi de l'activité normative; Link: https://www.conseil-etat. fr/ressources/etudes-publications/rappo rts-etudes/etudes/mesurer-1-inflation-norma tive)

1905-1938, «Annuaire Statistique de la France»(ASF), vol. 1966 Table XIIB: Financial situation of local government 1948-1978. ASF 1948-1988

1978-2015. INSEE. Expenditures and receipts of general government in 2015-National accounts-Base 2010, Table 3.215-Compulsory levies of general government and European Union institutions (billions of euros). Link: https://www. insee.fr/en/statistiques/2387925?somma ire $=2387999$ (consulted March 2020)

1905-1989. Yvert (1990)

1989-2015. The website of the French national assembly. Tous les gouvernements depuis 1958, Link:

http://www2.assemblee-nationale.fr/decouvrir-1-assemblee/histoire/la-ve-republique/ tous-les-gouvernements-depuis-1958 


\begin{tabular}{ll}
\hline Name & Description \\
\hline REPR & (1-inflation rate)*Debt/GDP
\end{tabular}

Source

INFLATION. The indicators of consumer prices in the different databases proposed by Mitchell (1975, Table H.2, Cost of Living/Consumer Price Indexes 1905-1914 $(1914=100)$. From 1914 to 1948 the base is from 1929, then for the period 1948-1965 the base is 1953, then the base goes from 1970 until 1993. The base changes again in 2000. Inflation rates have been calculated from these indicators taking into account the changes in base each time

PUBLIC DEBT. Years 1905-1939: Data from the Villa P./CEPII series. http://www.cepii .fr/francgraph/bdd/villa/mode.htm. Years 1940-1962: Data from the INSEE's Retrospective Statistical Yearbook dating from 1966 (pp. 494-495). Years 1963-1985:

Data from INSEE's retrospective statistical yearbook dating from 1990 (p. 619) (data from new francs; the conversion into euros of the entire series up to 1987 is done by switching to new francs when the figures are in old francs, then dividing by 6.55957 to convert to euros). Years 1986-2015: INSEE national accounts data

GDP. 1905-1950: Data from the Villa P series. Years 1950-1965: Data from the INSEE retrospective statistical yearbook of 1966 (pp. 555-556). Years 1966-1985: Data taken from the INSEE website, data in euros, so the conversion into new francs is made by multiplying the value in euros by 6.55957 (http://www.bdm.insee .fr/bdm2/affichageSeries.action?idban $\mathrm{k}=001625867 \&$ codeGroupe $=1336$ ). Years 1986-2015: INSEE national accounts data

UNEMPL Unemployment rate

1905-1975. Séries longues macroéconomiques Villa P./CEPII http://www.cepii.fr/ francgraph/bdd/villa/mode.htm

1975-2015; Unemployment rate forecast OECD, Link: https://data.oecd.org/unemp/ unemployment-rate-forecast.htm

RIGHT Percentage of seats held by right-wing deputies in the Lower Chamber of the French Parliament

Chamber of Deputies for the Third and Fourth Republic and National Assembly for the Fifth Republic excluding French departments and overseas territories

Website of the French National Assembly: http://www.assemblee-nationale.fr/histoire/ index.asp: distribution of the seats in the French National Assembly according to the different political parties

OPEN Ratio of the sum of exports and imports to 1905-1970, Asselain and Blancheton (2005) GDP 


\begin{tabular}{lll}
\hline Name & Description & Source \\
\hline PRES & Dummy $=1$ for presidential governments & The Third Republic and the Fourth Republic
\end{tabular}
were parliamentary regimes, while the Fifth Republic was a semi-presidential regime. Originally conceived as a parliamentary regime in which the powers of the executive were strengthened, following the 1962 referendum that established the election of the President of the Republic by direct universal suffrage, the Fifth Republic has become a semi-Presidential regime

DISPL Ratio between taxation and GDP

1905-1958: GDP data are from INSEE retrospective statistical yearbook. The data are in millions of old francs up to 1950 , then from 1951 onwards in billions of old francs. They are converted into euros using the conversion rate: $655.957 \mathrm{AF}=1 €$. It is estimated tat, even if it was not clearly mentioned in the yearbook, the amounts are in current values. The amounts obtained are therefore in current euros. After we calculate the share of receipts of general government on GDP

1959-2015, all the data come from INSEE [1959-2015. Expenditures and receipts of general government INSEE Link: https ://www.insee.fr/en/statistiques/23879 25 ? sommaire $=2387999$ and INSEE $1.101-$ Gross domestic product and its components at current prices (billions of euros) Link: INSEE https://www.insee.fr/en/statistiqu es/2387882? sommaire $=2387999$ ]

INTENSITY French government spending per page of See Total Government spending and Pages legislation

\section{A.2. France Official Journal editions and number of pages}

The idea for this work lies in the archives of the Cujas library of the Faculty of Law of Paris. We used their collection of Official Journals of French Republic. To count the number of pages we took the last page of the volume of the Official Journal on 31 December of each year. Between 1976 and 1983, a new layout was adopted, distinguishing the classic Official Journal pages from the pages marked CN, i.e., additional pages. However, this presentation was abandoned in 1985. On 1 January 2016, the JORF ceased to be a physical document. From then on, there has only been an electronic version published. Given this, it is no longer possible to count the number of pages of the French Official journal on the physical paper version, but only on the PDF version. The series, therefore, ends in 2015.

The Official Journal publishes the following documents every year: Laws (Parliament), Ordinances (Government), Decrees (activity of the 1st minister), Orders (activity of ministers), Circulars (activity of the administration in the broad sense), Administrative decisions (activity of the high administration), instructions and opinions. The circulars are, for instance, about defense, agriculture, education, health, security, ecology, housing, public function, administration, migration, finance, urban, firm, or foreign affairs. In 2015 the 
service of the prime minister counts 33 laws, 13 orders, 82 decrees and 75 administration decisions. Figure 4 presents the structure of the official journal for 3 years $(1920,1950$ and 2000). The legislative activity per se increases in 2000, but the overall structure is the same. However, the calculation has been done by hand and should be seen as an approximation. Figure 5 reports the number of laws and the number of articles at the promulgation for the period 2000-2017. (Fig. 5).

\section{References}

Aglietta, M. (1997). Régulation et crises du capitalism (3rd ed.). Paris: Odile Jacob.

Aglietta, M., \& Brender, A. (1984). Les métamorphoses de la société salariale. La France en projet. Paris: Calmann-Lévy.

André, C., \& Delorme, A. (1983). L'Etat et l'économi. Un essai d'explication de l'évolution des dépenses publiques en France 1870-1980. Paris: Éditions du Seuil.

Artus, P., \& Kaabi, M. (1993). Dépenses publiques, progrès technique et croissance. Revue Économique, 44, 287-318.

Asselain, J. C., \& Blancheton, B. (2005). Dynamique de l'ouverture internationale. Paradoxes, enjeux, éléments d'interprétation à partir du cas de la France. Economies et Sociétés, série histoire économique quantitative, $A F, 32,49-179$.

Bouvier, J. (1978). Histoire financière et problèmes d'analyse des dépenses publiques. Annales, 33, 207-215.

Brennan, G., \& Buchanan, J. M. (1980). The power to tax: Analytical foundations of a fiscal constitution. Cambridge: Cambridge University Press.

Burgess, R., \& Donaldson, D. (2015). Railroads and the demise of famine in colonial India. MIT, mimeo.

Cavallo, E., De Gregorio, J., \& Loayza, N. (2008). Output volatility and openness to trade: a reassessment. Brookings Institution Press, Economia, 9, 105-152.

Cofrey, B., McLaughlin, P., \& Peretto, P. (2016). The cumulative cost of regulations. Mercatus Working Paper, April 26. https://www.mercatus.org/publication/cumulative-cost.regulations.

Constant, B. (1822-1824). Commentaire sur l'ouvrage de Filangieri. Paris: Les Belles Lettres. Ed. 2004.

Djankov, S., McLiesh, C., \& Ramalho, R. (2006). Regulation and growth. Economics Letters, 92, 395-401.

Dudley, S., \& Warren, M. (2016). Regulators' budget increases consistent with growth in fiscal budget. An analysis of the U.S. budget for fiscal years 2015 and 2016. Annual Report 2015, Regulator budget report 37. Weidenbaum Center Regulatory Studies Center, Washington University; The George Washington University St. Louis, Washington. http://wc.wustl.edu and http://www.RegulatoryStudies.gwu. ed.

Easterly, W., Islam, R., \& Stiglitz, J. (2000). Explaining growth volatility. World Bank, January.

Facchini, F. (2003). La contractualisation des aides en agriculture: à qui doit-on donner les droits? Économie Rurale, 273, 243-250.

Facchini, F. (2019). What are the determinants of public spending? An overview of the literature. Atlantic Economic Journal, 46, 419-439.

Facchini, F., \& Melki, M. (2013). Efficient government size: France in the 20th century. European Journal of Political Economy, 31, 1-14.

Feldman, J. P. (2008). Le constitutionnalisme selon Benjamin Constant. Revue Française de Droit Constitutionnel, 76, 675-702.

Flora, P. (1983). State, economy, and society in western Europe 1815-1975. London: St. James Press.

Gilbert, G. (1984). Analyses critiques de Delorme R., \& André, C., L'état et l'économie. Un essai d'explication de l'évolution des dépenses publiques en France 1870-1980. Politiques et Management Public, 2, 148-152.

Haddad, M., Lim, J., Pancaro, C., \& Saborowski, C. (2013). Trade openness reduces growth volatility when countries are well diversified. Canadian Journal of Economics, 46, 765-780.

Herzog, P. (1973). A propos de la notion d'économie publique. Revue Économique, 24, 139-162.

Higgs, R. (1987). Crisis and leviathan. Critical episodes in the growth of American government. New York, NY: Oxford University Press.

Ikeda, S. (1997). Dynamics of the mixed economy: Toward a theory of interventionism. New York, NY: Routledge.

Kose, A., Prasad, E., \& Terrones, M. (2003). Financial integration and macroeconomic volatility. IMF Staff Papers, 50, 119-142. 
Lagona, F., Maruotti, A., \& Padovano, F. (2015). Multilevel multivariate modeling of legislative count data, with a hidden Markov chain. Journal of the Royal Statistical Society, Series A, 178, 705-723.

Lagona, F., \& Padovano, F. (2008). The political legislation cycle. Public Choice, 134, 201-229.

Lamoreaux, N. R., \& Rosenthal, J. L. (2005). A comparison of business's organizational choices in France and the United States during the era of industrialization. American Law and Economics Review, 7, 28-61.

Mills, P., \& Quinet, A. (1992). Dépenses publiques et croissance. Revue Française d'Economie, 7, $29-60$.

Mises, L. (1929). A critique of interventionism. New Rochelle: Arlington House, ed. 1977.

Mitchell, B. R. (1975). European historical statistics, 1750-1970. London: Palgrave-MacMillan.

Myers, R. H. (1990). Classical and modern regression with applications. Boston, MA: PWS-Kent.

Nkoro, E., \& Uko, A. K. (2016). Autoregressive distributed lag (ARDL) cointegration technique: application and interpretation. Journal of Statistical and Econometric Methods, 5, 63-91.

Oates, W. E. (1972). Fiscal federalism. New York, NY: Harcourt Brace Jovanovich.

Peacock, A. T., \& Wiseman, J. (1961). The growth of public expenditure in the United Kingdom. Princeton, NJ: Princeton University Press.

Persson, T., \& Tabellini, G. (1999). The size and scope of government: Comparative politics with rational politicians. European Economic Review, 43, 699-735.

Pesaran, M. H., \& Pesaran, B. (1997). Working with Microfit 4.0: Interactive econometric analysis. Oxford: Oxford University Press.

Pesaran, M. H., \& Shin, Y. (1999). An autoregressive distributed lag modeling approach to cointegration analysis. In S. Strom (Ed.), Econometrics and economic theory in the 20th century. Cambridge: Cambridge University Press.

Pesaran, M. H., Shin, Y., \& Smith, R. J. (2001). Bounds testing approach to the analysis of level relationships. Journal of Applied Economics, 16, 289-326.

Pickering, A., \& Rockey, J. (2011). Ideology and the growth of government. The Review of Economics and Statistics, 93, 907-919.

Prohl, S., \& Schneider, F. (2009). Does decentralization reduce government size? A quantitative study of the decentralization hypothesis. Public Finance Review, 37, 639-664.

Rajhi, T. (1993). Croissance endogène et externalités des dépenses publiques. Revue Économique, 44, 335-368.

Rangeon, F. (1986). L'idéologie de l'intérêt général, préface de Georges Vedel. Paris: Economica.

Reinhart, C., Kirkegard, J. F., \& Sbrancia, M. B. (2011). Financial repression redux. Finance and Development, 48, 24-26.

Reinhart, C., \& Sbrancia, M. B. (2015). The liquidation of government debt. IMF working paper no. $\mathrm{WP} / 15 / 7$.

Rodrik, D. (1998). Why do more open economies have bigger governments? The Journal of Political Economy, 106, 997-1032.

Roe, M. J. (1994). Strong managers, weak owners. Princeton, NJ: Princeton University Press.

Roe, M. J. (2003). Political determinants of corporate governance. Oxford: Oxford University Press.

Rosanvallon, P. (1990). L'etat en France de 1789 à nos jours. Paris: Éditions du Seuil.

Shughart, W. F., II. (2018). Selective consumption taxes in historical perspective. In A. J. Hoffer \& T. Nesbit (Eds.), For your own good: Taxes, paternalism, and fiscal discrimination in the twenty-first century. Arlington, TX: Mercatus Center at George Mason University.

Shughart, W. F., II, \& Tollison, R. D. (1986). On the growth of government and the political economy of legislation. Research in Law and Economics, 9, 111-127.

Vianes, A. (1980). La raison économique d'etat. Lyon: Presses Universitaires de Lyon.

Volkerink, B., \& de Haan, J. (2001). Fragmented government effects on fiscal policy: New evidence. Public Choice, 109, 221-242.

Yelvington, B. (1997). Excise taxes in historical perspective. In W. F. Shughart II (Ed.), Taxing choice: The predatory politics of fiscal discrimination. New Brunswick: Transaction.

Yvert, B. (1990). Dictionnaire des ministres (1789-1989). Paris: Perrin.

Publisher's Note Springer Nature remains neutral with regard to jurisdictional claims in published maps and institutional affiliations. 